\title{
Dose-Response Analysis of Effects of Antibodies to Large Ganglion Cells on the Cat's Retinogeniculate Pathways
}

\author{
John W. Crabtree, ${ }^{1}$ Peter D. Spear, Maureen A. McCall, Lillian Tong, Kim R. Jones, ${ }^{2}$ and \\ Steven E. Kornguth \\ Departments of Psychology and Neurology, Neuroscience Training Program, University of Wisconsin, \\ Madison, Wisconsin 53706
}

Previous studies have shown that antibodies against large retinal ganglion cells (alpha-/Y-cells) reduce the $Y$-cell retinogeniculate pathway while having little or no effect on the $\mathrm{X}$ - or W-cell pathways. The present study investigated the doseresponse relationship of these effects. We began by studying effects on the T1 (largely Y-cell-mediated) and T2 (largely X-cellmediated) waves of the retinal field-potential. Different concentrations of the antibodies were injected intraocularly in adult cats and retinal field-potentials evoked by optic chiasm stimulation were examined. The lowest concentration of immune serum tested $(330 \mu \mathrm{g} / 100 \mu \mathrm{l}$ volume) reduced both the $\mathrm{T1}$ and T2 amplitudes. With increasing concentrations, the ratio of T1:T2 amplitudes progressively decreased from 0.71 to only 0.05 . The highest concentration of immune serum tested $(1000 \mu \mathrm{g} /$ $100 \mu l$ volume) virtually eliminated the $T 1$ wave while the $T 2$ wave remained (albeit reduced).

Next, we carried out single-cell physiological and morphological studies to verify the effects of the highest antibody concentration and compare them with previous results on effects of the lowest antibody concentration (Kornguth et al., 1982; Spear et al., 1982). In single-cell recordings from the retina, the encounter rates of $Y$ - and $X$-cells were reduced by 85 and $53 \%$, respectively, after injection of the highest antibody concentration. There was no effect on the encounter rate of retinal $W$-cells. After injection of the lowest antibody concentration, there was no change in the encounter rates of any of the retinal cell types.

Morphological studies revealed an 88-99\% loss of alpha-cells in retinae treated with the highest antibody concentration. There also was a substantial (24-57\%) loss of medium-size ganglion cells but no loss of small ganglion cells. The loss of alpha-cells was much greater after high-concentration injections than after low-concentration injections.

In recordings from the $L G N$, the proportion of $Y$-cells was reduced by $87 \%$ in laminae receiving input from an eye injected with the highest antibody concentration. Laminae receiving input from an eye injected with the lowest concentration had a $\mathbf{7 7 \%}$ reduction in Y-cells. The encounter rate of $L G N$ X-cells was not affected by either concentration. Morphological analysis indicated that the loss of Y-cells in the LGN was not due to changes in cell size.

\footnotetext{
Received Jan, 21, 1985; revised Oct. 22, 1985; accepted Oct. 30, 1985.

This work was supported by United States Public Health Service Research Grants EY01916 and EY02545 (P.D.S.) and United States Public Health Service Visual Sciences Training Grant EY07059 to the University of Wisconsin. We thank Ms. Kathleen Vielhuber and Ms. Stephanie Miller for their excellent technical assistance.

Correspondence should be addressed to P. D. Spear, Department of Psychology, University of Wisconsin, 1202 West Johnson St., Madison, WI 53706.

1 Present address: Department of Human Anatomy, South Parks Road, Oxford OX1 3QX, England.

2 Present address: University of North Carolina School of Medicine, Chapel Hill, NC 27514.

Copyright (C) 1986 Society for Neuroscience $0270-6474 / 86 / 051199-12 \$ 02.00 / 0$
}

These findings indicate that antibody-mediated effects on retinogeniculate pathways are dose-dependent. Furthermore, when a sufficiently high antibody concentration is used, there is a nearly complete loss of the $Y$ pathway, a partial loss of the $X$ pathway, and no apparent loss of the $W$ pathway. The results also provide some insights into the mechanisms of the antibody action and have implications for an understanding of retinogeniculate neural processing.

Ganglion cells in the cat retina have been grouped into several functional classes on the basis of their receptive-field organizations, dynamic response properties, and axonal conduction velocities (Cleland and Levick, 1974a, b; Cleland et al., 1971; Enroth-Cugell and Robson, 1966; Fukada, 1971; Stone and Fukuda, 1974; Stone and Hoffmann, 1972). Two of these classes, referred to as $\mathrm{X}$ (or brisk sustained) and $\mathrm{Y}$ (or brisk transient) have quite distinct properties and are relatively homogeneous. A third class, referred to as $W$, is a heterogeneous grouping that includes cells with low visual sensitivity, relatively sluggish responses, and nonconcentric receptive fields. Cat ganglion cells also have been grouped into a number of morphological classes, which differ in soma sizes and dendritic branching patterns (Boycott and Wässle, 1974; Kolb et al., 1981; Leventhal et al., 1985). Alpha-cells have the largest somata, and there is good evidence that they correspond to the $Y$-cell functional class (Cleland et al., 1975; Fukuda et al., 1984; Peichl and Wässle, 1981; Saito, 1983a, b; Stanford and Sherman, 1984). There also appears to be a correspondence between morphological betacells and physiological X-cells, while W-cells appear to correspond to other morphological types such as gamma-, delta-, and epsilon-cells (Fukuda et al., 1984; Saito, 1983a, b; Stanford and Sherman, 1984). The retinal outputs of these three functional classes of cells tend to remain separate in their projections to central visual structures (Lennie, 1980; Sherman and Spear, 1982; Stone, 1983; Stone et al., 1979). For example, the X, Y, and $\mathrm{W}$ functional pathways are relayed in parallel through the LGN to visual cortex (Cleland et al., 1971, 1976; Hoffmann et al., 1972; Wilson et al., 1976).

In order to learn more about the contributions that the X-, $\mathrm{Y}$-, and $\mathrm{W}$-cell pathways make to visual function, we have initiated studies using immunoablation methods to selectively eliminate one of the pathways. In previous experiments (Kornguth et al., 1981, 1982; Spear et al., 1982), we found that intraocular injection of purified immunoglobulins directed against the large (alpha/Y) retinal ganglion cells produces an average loss of $32 \%$ of large ganglion cells in the cat retina. This effect is relatively selective in that there is little or no loss of mediumor small-diameter ganglion cells. In addition, single-cell recordings from $L G N$ laminae $A$ and $A 1$ reveal a $77 \%$ reduction in the number of $Y$-cells and no effect on the number of $X$-cells encountered.

Several factors prompted us to investigate the dose-response relationship of the antibody-mediated loss of retinal ganglion 
cells. First, with the antibody concentration used in our initial studies, the morphological loss of retinal alpha-cells was far from complete. In addition, the alpha-cell loss was unevenly distributed in patches or streaks across the retina of each eye, and the total loss was relatively variable from retina to retina (range 8$61 \%$ ). We wished to determine if higher concentrations of the antibodies would produce a more complete and consistent alpha-cell loss. Second, despite the morphological loss of retinal alpha-cells and the physiological loss of LGN Y-cells, we were unable to detect a physiological loss of retinal Y-cells in singlecell recordings from antibody-treated eyes. This inconsistency wàs interpreted to result from sampling error in single-cell recordings from the retina (Spear et al., 1982; cf. Stone, 1973). We wished to determine if higher concentrations of the antibodies would produce a retinal $Y$-cell loss that could be detected with single-cell recordings. Third, the mechanisms of the antibody-mediated effects are not fully understood. We hoped to learn more about these mechanisms by studying the dose-response relationship of the effects.

In the present investigation, we began by assessing the effects of different concentrations of intraocularly injected antibodies on the function of large populations of $\mathrm{X}$ - and $\mathrm{Y}$-cells in the retina. Such an assessment can be made from an analysis of retinal field-potentials evoked by electrical stimulation of the optic chiasm because the conduction velocities of the $T 1$ and T2 field-potential waves (G. H. Bishop et al., 1969; P. O. Bishop and McLeod, 1954; P. O. Bishop et al., 1953) indicate that these waves largely correspond to the compound action potentials of Y-and X-cell axons, respectively (Cleland et al., 1971; Fukada, 1971; Rowe and Stone, 1976a). We found that the antibody injections produce a large reduction of the $\mathrm{T} 1$ wave and smaller reduction of the $T 2$ wave. The reduction of the $T 1$ wave was dose-dependent, and injection of the highest antibody concentration tested virtually eliminated this wave while the $\mathrm{T} 2$ wave remained (albeit reduced). To verify the effects of the highest antibody concentration, we then studied the morphology and physiology of single neurons in the retina and LGN. These results were compared to those from cats given low-concentration antibody injections and from normal cats in this and previous (Kornguth et al., 1982; Spear et al., 1982) studies.

\section{Materials and Methods}

Most of the methods have been described in detail elsewhere (Kornguth et al., 1981, 1982; Spear et al., 1982) and will only be summarized here.

\section{Preparation of antibodies against large ganglion cells}

Antibodies were produced by immunizing rabbits with a suspension of large ganglion cclls (diamcter $>28 \mu \mathrm{m}$ ) isolated from ox retinae (Kornguth et al., 1981, 1982). Unpurified serum, having a concentration of $10 \mathrm{mg}$ IgG plus IgM (primarily IgG) per milliliter before dilution, was used for the present experiments. Unpurified immunoglobulins were used because the antibody titer was higher than that present after purification by column chromatography. Consequently, we could test a wider range of concentrations. Direct comparison of the effects of equal concentrations of purified and unpurified immunoglobulins on retinal alpha-cells and on retinal field-potentials indicated that similar results are obtained with each. Control non-immune rabbit gamma-globulins were obtained commercially (Miles Laboratories).

\section{Subjects and gamma-globulin administration}

Twenty-two adult cats (either sex) were given an injection of unpurified immunoglobulins into the vitreous chamber of one or both eyes. A total of $100 \mu \mathrm{l}$ sterile PBS (pH 7.2) containing from 330 to $1000 \mu \mathrm{g}$ of immunoglobulin (IgG plus IgM) was injected in three equal pulses over 5 min. In six of the cats, control gamma-globulins were injected into the vitreous chamber of the other eye. The carrier solution, concentration of gamma-globulins, and method of injection were the same as for the immunoglobulin injections.
Physiological results from nine antibody-treated cats studied previously (Spear et al., 1982) were included for comparison with the present series. Recordings were made from retinal or LGN neurons using methods identical to those of the present experiments. In addition, the retinae of six cats from a previous morphological study (Kornguth et al., 1982) were reexamined using new morphometric sampling methods, and the results were compared with those from the present series. Animals studied in the previous experiments received a $330 \mu \mathrm{g}$ antibody injection in one eye and either no injection or a control gamma-globulin injection in the other eye.

Normative data were obtained from 19 adult cats with no treatment. Thirteen of these were from earlier studies of retinal or LGN neurophysiology (Geisert et al., 1982; Spear et al., 1982; Tong et al., 1982). The remaining six normal cats were added in the present series and were studied using methods identical to those employed previously.

\section{Retinal neurophysiology}

\section{Animal preparation}

During initial surgery the cat was anesthetized with halothane in $50 \%$ $\mathrm{N}_{2} \mathrm{O} / 50 \% \mathrm{O}_{2}$. The animal was mounted in a specially designed stereotaxic apparatus, and a bilateral pneumothorax was performed. A pair of electrodes was placed in the optic chiasm (OX) for electrical stimulation. Paralysis was induced and maintained throughout recording by intravenous infusion of gallamine triethiodide and tubocurarine chloride. The cat was artificially respired via a tracheal cannula, and the end-expired $\mathrm{CO}_{2}$ was maintained at $4.0 \%$. Heart rate was monitored continuously, and body temperature was held at $38^{\circ} \mathrm{C}$ with a heating pad. All wound edges were infiltrated with a long-lasting local anesthetic. During recording the animal was respired with $75 \% \mathrm{~N}_{2} \mathrm{O} / 25 \% \mathrm{O}_{2}$.

The pupils werc dilated and accommodation was blocked by topical application of $1 \%$ ophthalmic atropine sulfate. The corneas were protected with zero-power contact lenses. For single-cell recording experiments, the corneal contact lenses contained a $3 \mathrm{~mm}$ diameter artificial pupil, and spectacle lenses were used to focus the eyes on a tangent screen placed $114 \mathrm{~cm}$ from the nodal points. The positions of the optic disk and area centralis were projected and plotted on the tangent screen (Fernald and Chase, 1971). Closed-eye intraocular methods were used to record from the retinal surface (Schiller and Malpeli, 1977; Spear et al., 1982).

\section{Visual and electrical stimulation}

Flashing or moving spots of light were presented on the tangent screen with a hand-held projector or with an automated projector system. In addition, sine-wave grating stimuli were presented on a Hewlett-Packard $1332 \mathrm{~A}$ display monitor with a mean luminance of $30 \mathrm{~cd} / \mathrm{m}^{2}$. Grating parameters were controlled by an Innisfree CRT image generator. Bipolar electrical stimulation of the OX was delivered via a stimulusisolation constant-current unit. Stimuli were $50 \mu \mathrm{sec}$ pulses and current was varied systematically between 0.1 and $10 \mathrm{~mA}$.

\section{Field-potential recording}

Retinal field-potentials were evoked by electrical stimulation of the $O X$. The field-potentials were recorded from the optic disk with a $4 \mathrm{M} \mathrm{NaCl}$ filled micropipette. Electrode impedance was $15-20 \mathrm{M} \Omega$, measured with a $135 \mathrm{~Hz}$ sine-wave input. The electrode tip was positioned in the center of the optic disk (viewed with an ophthalmoscope), and recordings were made approximately $200 \mu \mathrm{m}$ below the optic disk surface. Signals were amplified with $30 \mathrm{~Hz}$ to $10 \mathrm{kHz}$ bandpass filters and led to a storage oscilloscope from which photographic records were made. Field-potential latencies were measured from the beginning of the stimulus pulse to the point of onset of the negative-wave deflection and to the point of maximal negative deflection of each wave. Amplitude was measured as the voltage difference between these two points (sec example in Fig. 1 , bottom left).

\section{Single-cell recording}

Recordings were made from single ganglion cell somata using micropipettes similar to those described above. An area of the retinal surface extending from $5^{\circ}$ to $15^{\circ}$ nasal to the area centralis and from $8^{\circ}$ above to $8^{\circ}$ below the zero horizontal meridian was studied. To obtain an estimate of the absolute sampling density of ganglion cells, a systematic sampling procedure was employed in which successive microelectrode 
penetrations were separated by $230 \mu \mathrm{m}$ (approximately $1^{\circ}$ of visual angle) on the retinal surface. All results are for cell soma recordings only-see Spear et al. (1982) for criteria.

Four main tests were used to classify cells as X, Y, or W. These tests were receptive-field center size, cutoff velocity, linearity of spatial summation, and response latency to OX stimulation. Except for linearity of spatial summation, these tests are the same as those used in our earlier study of retinal ganglion cell responses (Spear et al., 1982). In the present experiments, linearity of spatial summation was tested using a counterphased sine-wave grating with a spatial frequency just below the cutoff for the cell being studied (Hochstein and Shapley, 1976). Criteria for classifying a cell as X, Y, or W were the same as those described previously (Spear et al., 1982).

\section{Retinal anatomy}

\section{Preparation of retinal whole-mounts}

Cats were given an overdose of sodium pentobarbital and were perfused transcardially with $0.9 \%$ saline followed by $10 \%$ formol saline. Each retina was dissected from the eyecup and floated, fiber layer up, onto a gelatinized slide. The retinae were fixed to the slides by exposure to formalin vapors and then dehydrated through a series of alcohols, cleared in xylene, rehydrated, and stained with cresyl violet.

\section{Alpha-cell density measures}

The density of large (alpha) ganglion cells from selected retinal areas was determined from the whole-mounts using a Nikon Biophot microscope with a $10 \times$ objective and a $10 \times$ eyepiece that contained a square grid reticle. The number of large ganglion cells was counted in five $2 \times 2 \mathrm{~mm}$ areas. One of these areas was centered on the area centralis, and the other four were centered $2 \mathrm{~mm}$ from area centralis on the zero horizontal and vertical meridia in the nasal, temporal, superior, and inferior quadrants. Within each retinal field examined, the large (alpha) ganglion cells were easily distinguishable from those of smaller sizes (Hughes, 1975; Rowe and Stone, 1976b; Stone, 1978; Wässle et al., 1975 ) and, therefore, were identified by inspection.

\section{Soma size measures}

Cross-sectional areas were measured for all ganglion cells within a field centered in each of the five retinal areas described above. This field was $160 \times 160 \mu \mathrm{m}$ at the area centralis and $400 \times 400 \mu \mathrm{m}$ at each of the four peripheral locations. Outlines of neurons were drawn in the plane of focus of the nucleolus at a total magnification of $1000 \times$ (oil-immersion objective) using a camera lucida attachment to the microscope. Cross-sectional areas were measured with an electronic planimeter (Numonics graphics calculator) interfaced with a PDP-11/34 computer, without correction for tissue shrinkage.

\section{LGN neurophysiology}

\section{Animal preparation, stimulation, and recording}

These procedures were similar to those used for single-cell recording in the retina. To record from the LGN, trephine holes were made at appropriate locations in the skull and the dura was excised. Extracellular recordings were made with varnish-coated tungsten microelectrodes. Electrode impedance was 45-65 M $\Omega$ measured with a $135 \mathrm{~Hz}$ sine-wave input.

\section{Sampling and classification of cells}

LGN laminae A and Al were studied in all cats and both hemispheres (ipsilateral and contralateral to the treated eye) were studied in cats with antibody injections. While searching for single-cell recordings in the LGN, the electrode was advanced slowly in $5 \mu \mathrm{m}$ steps and spots of light were moved or flashed on the tangent screen. Once a penetration was started through an LGN lamina, it was terminated only after the lamina had been completely traversed. All results are for cell-body recordings only (see P. O. Bishop et al., 1962; Spear et al., 1982). The tests used to classify LGN cells were identical to those used for retinal ganglion cells. The criteria for classifying cells as X, Y, or mixed have been described in detail elsewhere (Spear et al., 1982).

\section{Histological verification}

In each LGN studied, the location of the electrode tip was marked with small electrolytic lesions in two positions along the last penetration that was made. Electrode tract reconstructions from sections through the LGN (Spear et al., 1982) indicated that all data were from cells in laminae $\mathrm{A}$ and $\mathrm{Al}$.

\section{LGN morphology}

For cach animal, a single block of tissue containing both LGN was embedded in celloidin, and serial coronal sections were cut at $52 \mu \mathrm{m}$ and stained with cresyl violet. Cross-sectional areas were measured for neurons in laminae A and Al of both hemispheres. Measurements were made from sections cut at stereotaxic plane +6.5 and at the mediolateral midpoint of the binocular segment of the nucleus. This corresponds to the representation of approximately the zero horizontal meridian at $10^{\circ}$ azimuth. Cells were sampled in a single sweep through the dorsoventral extent of each lamina. Outlines of neurons showing a well-defined nucleolus were drawn at a magnification of $1000 \times$ (oil immersion) using a camera lucida atlachment to the microscope. Cross-sectional areas were measured as described for retinal cell measurements. Measurements were made without knowledge of which LGN laminae received inputs from the immunoglobulin-injected eye.

\section{Results}

\section{Retinal neurophysiology}

\section{Field-potentials}

Recordings were made from the optic disk in 15 antibody-injected eyes of 11 cats. Recordings were made $21-41 \mathrm{~d}$ after the injections, and there was no relationship between survival time and the results that were obtained. Field-potential recordings also were made in six normal eyes of five cats and in a controlinjected eye of one cat. In many cats, the two eyes received different treatments (e.g., different antibody concentrations, or an antibody injection in one eye and no injection in the other), and both eyes were studied using the same recording electrode.

Figure 1 shows examples of the antidromic field-potentials evoked by electrical stimulation of the OX. In both the normal and the antibody-injected eyes, the potentials evoked by suprathreshold stimulation consisted of two temporally separate wave deflections. The temporal pattern of these waves remained virtually constant over the full range of current intensities. In several cases, we examined the effects of changing the depth and location (nasal-temporal, superior-inferior) of the recording electrode in the optic disk. The temporal pattern and relative amplitudes of the two field-potential waves were unaffected by these changes.

For normal eyes, the conduction velocities of the two fieldpotential waves were estimated using the latency measurements (Fig. 1, bottom left) and an OX to optic disk distance of 22.9 $\mathrm{mm}$ (Berson and McIlwain, 1983). For the first wave, the onset (O1) velocity for individual eyes ranged from $311065 \mathrm{~m} / \mathrm{sec}$ (mean $42 \mathrm{~m} / \mathrm{sec}$ ) and the maximal deflection (M1) velocity ranged from 23 to $42 \mathrm{~m} / \mathrm{sec}$ (mean $29 \mathrm{~m} / \mathrm{sec}$ ). For the second wave, the onset $(\mathrm{O} 2)$ velocity ranged from 15 to $27 \mathrm{~m} / \mathrm{sec}$ (mean 21 $\mathrm{m} / \mathrm{sec}$ ) and the maximal deflection (M2) velocity ranged from 12 to $20 \mathrm{~m} / \mathrm{sec}$ (mean $16 \mathrm{~m} / \mathrm{sec}$ ). These values for the normal eyes enabled us to identify the first and second waves as the T1 and T2 waves, respectively (G. H. Bishop et al., 1969; P. O. Bishop et al., 1953). Note that the onset conduction velocities of these waves corresponds to the conduction velocities of retinal Y- and X-cell axons, respcctively (Cleland and Levick, 1974a; Fukada, 1971; Hoffmann et al., 1972). For the antibodyand control-injected eyes, the onset and maximal deflection latencies of the two field-potential waves were not significantly different from normal. This also allowed us to identify each wave recorded in the injected eyes as being either T1 or T2. Therefore, this nomenclature will be used from here on. 
NORMAL

$\mathrm{mA}$

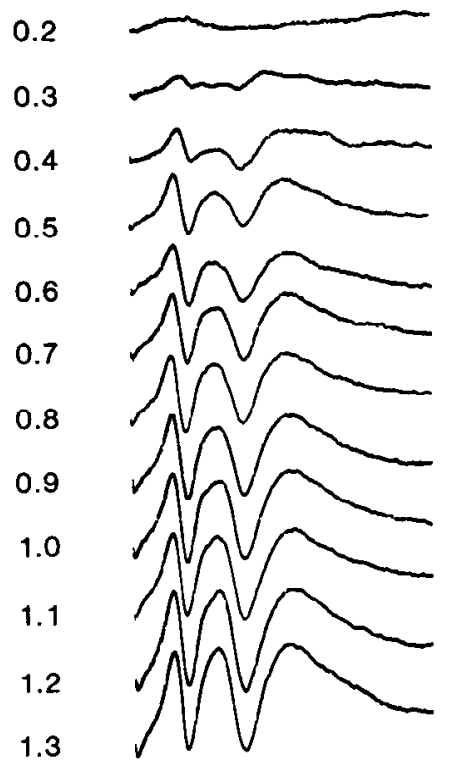

\section{ANTIBODY} $(1000 \mu \mathrm{g})$

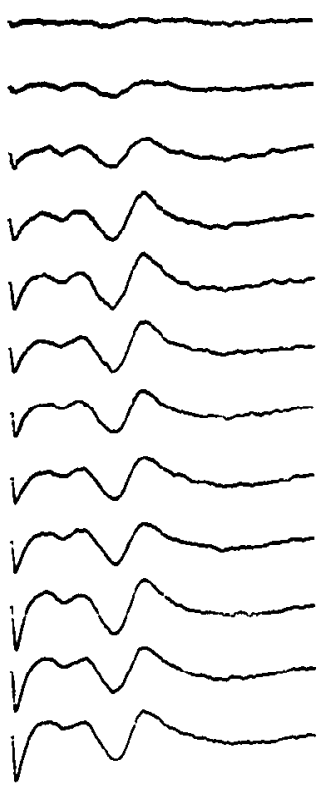

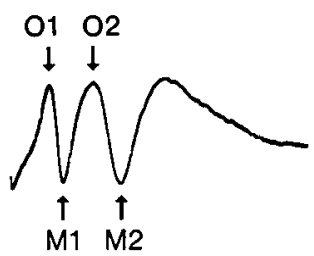

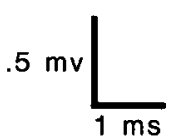

Figure 1. Field-potentials recorded from the optic disk of a normal eye (left) and an eye injected with the $1000 \mu \mathrm{g} / 100 \mu \mathrm{l}$ antibody concentration (right). The potentials were antidromically evoked by electrical stimulation of the optic chiasm using a series of increasing stimulus currents. Each trace shows the response to a single stimulus, which occurred at the beginning of the sweep. Negative deflections are downward. Two latency measures were made for each of the two early negative waves in the field-potentials (example at the bottom). The first measure was onset latency of each negative deflection $(O 1$ and $O 2)$. The second was the latency of the maximal negative deflection ( $M I$ and $M 2$ ). The amplitude of each negative wave was measured from the point of onset to the point of maximum deflection (i.e., the voltage difference between $\mathrm{O} 1$ and $\mathrm{M} 1$ and between $\mathrm{O} 2$ and $\mathrm{M} 2$ ). Voltage and time calibrations, bottom right. The sharp negative deflection at the beginning of each sweep is the shock artifact.

Figure 1 also shows the effects of different current intensities on the T1 and T2 wave amplitudes. As stimulus intensity increased, the amplitudes of T1 and T2 initially increased and then reached plateaus of stable amplitude values. These plateaus of maximal T1 and T2 wave amplitudes were used for analysis of the effects of different antibody concentrations. Because the maximal amplitudes obtained from the control-injected eye fell within the normal range, they were included with the normative data.

Figure 2 (left) shows the maximal T1 and T2 amplitudes obtained from normal and control-injected eyes and from eyes injected with various antibody concentrations. Relative to nor$\mathrm{mal} / \mathrm{control}$ eyes, there was a substantial decrease in both the $\mathrm{T} 1$ and T2 amplitudes in eyes treated with the lowest antibody concentration ( $330 \mu \mathrm{g} / 100 \mu \mathrm{l}$ volume). With increasing antibody concentrations, the T2 amplitude remained constant while the T1 amplitude steadily declined further. At the highest antibody concentration $(1000 \mu \mathrm{g} / 100 \mu \mathrm{l})$, the $\mathrm{Tl}$ wave was absent in three of the six eyes tested while the $\mathrm{T} 2$ wave was clearly present in all cases.

Figure 2 (right) shows the ratios of the maximal $\mathrm{T} 1$ to $\mathrm{T} 2$ amplitudes. In normal/control eyes, the mean $\mathrm{T} 1: \mathrm{T} 2$ ratio was 0.82 . With increasing antibody concentrations there was a progressive decline in the T1:T2 ratio. The mean ratio was 0.71 in eyes treated with the lowest antibody concentration and only 0.05 in eyes treated with the highest concentration.

Together, these field-potential results indicate that intraocular antibody injections reduce the amplitude of both the $\mathrm{Tl}$ and $\mathrm{T} 2$ waves and that, at least for the T1 wave, this effect is dosedependent. To the extent that the $\mathrm{T} 1$ and $\mathrm{T} 2$ waves are produced by axons of retinal $\mathrm{Y}$ - and X-cells, respectively, these results suggest that the highest antibody concentration produces a massive loss of Y-type ganglion cells and a much smaller loss of $\mathrm{X}$-type ganglion cells. In order to test this suggestion directly, and also to assess effects on the retinal W-cells, we next recorded from single ganglion cells in eyes injected with the highest antibody concentration.

\section{Single-cell recording}

In five cats, recordings were made from retinal ganglion cells in an eye injected with the highest antibody concentration (1000 $\mu \mathrm{g} / 100 \mu \mathrm{l}$ ). (Three of these cats also were used for field-potential recording.) Recordings were made 21-61 d after the injections, and there was no relationship between survival time and the results that were obtained. For comparison, recordings were made in two normal eyes, data from which were combined with data from six normal eyes studied previously (Tong et al., 1982).

The overall sampling density of retinal ganglion cells was markedly reduced in eyes given a high-concentration antibody injection. In normal eyes, soma recordings were encountered in $38 \%$ (169 of 449 ) of the retinal penctrations, whercas soma recordings were encountered in only $22 \%$ (57 of 256 ) of the penetrations in antibody-treated eyes. Figure 3 shows the retinal sampling density separately for each class of ganglion cells. Compared to normal eyes (Fig. 3, left), there was an $85 \%$ reduction in $\mathrm{Y}$-cells encountered in eyes given a high-concentration antibody injection (Fig. 3, right) $(U=0, p=0.001$; one-tailed Mann-Whitney test). In addition, there was a 53\% reduction in the encounter of X-cells following high-concentration antibody injections $(U=0, p=0.001)$. There was no significant effect of the high-concentration antibody injections on the encounter of W-cells.

The response properties of three of the five Y-cells encountered in eyes given a high-concentration antibody injection appeared to be abnormal in that the cells responded somewhat sluggishly to visual stimulation. These cells were classified as $\mathrm{Y}$ - rather than W-cells because they gave short-latency responses to OX stimulation or had high cutoff velocities, unlike W-cells. The response properties of the other two Y-cells and of the $\mathrm{X}$-and W-cells that were encountered appeared normal. That is, for cells of each class, receptive-field size, linearity of spatial summation, cutoff velocity, and axonal conduction velocity were within the normal range for that class. In addition, response rates appeared qualitatively normal. These findings suggest that the loss of ganglion cells is not due to generalized retinal trauma. They also suggest that the antibodies produce a loss of cells with a correlated array of response properties and not just an alteration of a particular response property used to classify cells.

In our previous study, we could detect no significant reduction in the encounter rate of ganglion cells in five eyes given a lowconcentration $(330 \mu \mathrm{g} / 100 \mu \mathrm{l} \mathrm{vol})$ antibody injection (Spear et al., 1982). In two of the eyes, the retinal area sampled was identical to that studied in the present experiment, and their results are presented in Figure 3 (middle). Comparison with the data following high-concentration injections suggests that the 


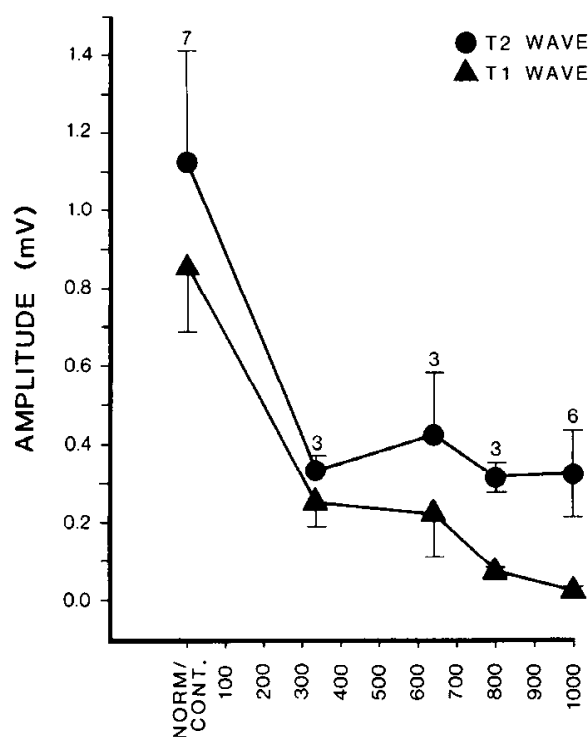

ANTIBODY CONCENTRATION $(\mu \mathrm{g})$

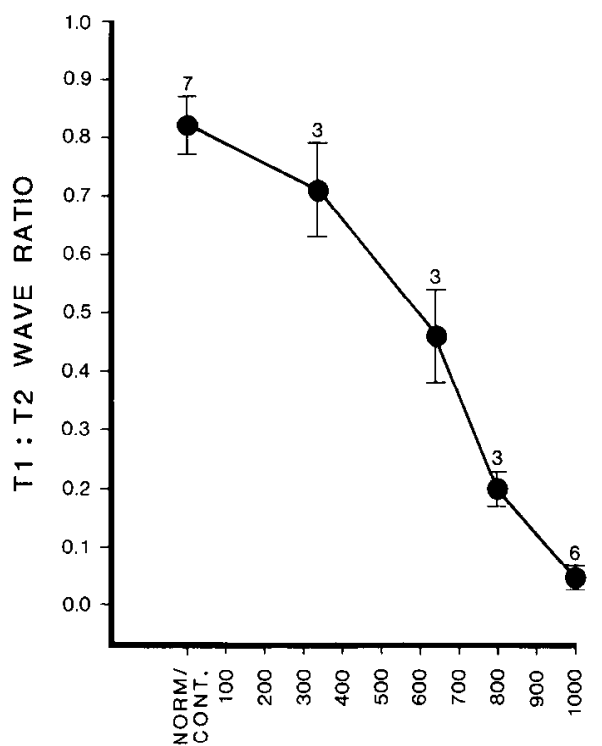

ANTIBODY CONCENTRATION ( $\mu \mathrm{g})$
Figure 2. Left, Amplitudes of the T1 wave (triangles) and T2 wave (circles) of the retinal field-potentials evoked in normal or control-injected eyes (NORM/CONT.) and in eyes injected with various antibody concentrations. Symbols represent means and brackets represent SEM of the wave amplitudes in individual eyes. The number above each pair of symbols gives the total number of eyes studied in that condition. Right, Ratios of the T1 to T2 wave amplitudes of the retinal field-potentials for the same eyes. Circles represent the means and brackets represent the SEM among individual eyes. The number above each circle gives the total number of eyes in that condition. effects of the antibodies on both X- and Y-cells are dose-dependent.

\section{Retinal anatomy}

\section{Alpha-cell density}

Counts of large (alpha) ganglion cells were made in both eyes of four cats given a monocular antibody injection. Two of the cats received a low-concentration $(330 \mu \mathrm{g} / 100 \mu \mathrm{l})$ antibody injection and two received a high-concentration $(1000 \mu \mathrm{g} / 100 \mu \mathrm{l})$ injection. (Two of these cats also had been used for retinal neurophysiology.)

As noted in Material and Methods, the alpha-cell counts were made from five sample areas in each retina. For each area, the numbers from the two eyes of each cat were compared to obtain an estimate of the percentage of alpha-cells lost after the antibody injection. [Here and elsewhere in the text, we refer to the reduced number of large (alpha) ganglion cells as a loss. The

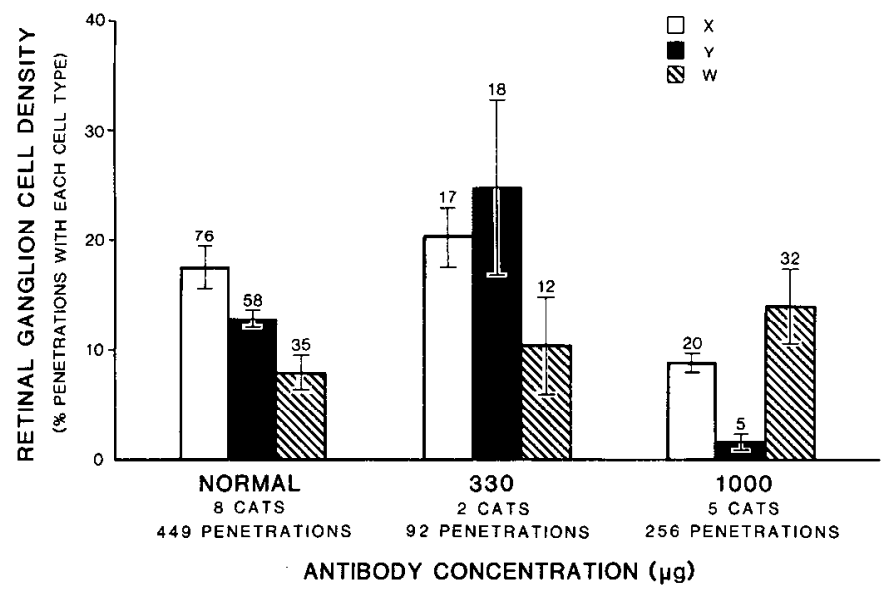

Figure 3. Percentage of retinal penetrations in which X-, Y-, or W-cells were encountered in normal eyes and eyes injected with either the low $(330 \mu \mathrm{g} / 100 \mu \mathrm{l})$ or high $(1000 \mu \mathrm{g} / 100 \mu \mathrm{l})$ antibody concentrations. Bars represent means and brackets represent SEM of the percentage of cells in each class encountered among individual animals. The total number of cats and penetrations is indicated below the bars. The number above each bar gives the total number of cells in a class, pooled across animals. alternative is that these cells are present but reduced in size. This possibility is addressed in the Discussion and considered unlikely.] To verify that the sampling procedure provides a valid measure of the overall alpha-cell loss, the present methods were used to reexamine the retinae from a previous study in which all alpha-cells had been counted (Kornguth et al., 1982). In that study, six cats were given a low-concentration $(330 \mu \mathrm{g} / 100 \mu \mathrm{l})$ antibody injection in one eye and either a control injection or no injection in the other eye. Values from the two methods differed by only $1-9 \%$ (mean $6 \%$ ) in individual animals. Therefore, the sampling method used in the present study provides a valid measure of the overall alpha-cell loss. In the results that follow, the reanalyzed data from the six earlier cats are combined with those from the two additional cats that received a lowconcentration injection in the present experiment.

As shown in Figure 4, the antibodies clearly produced a loss

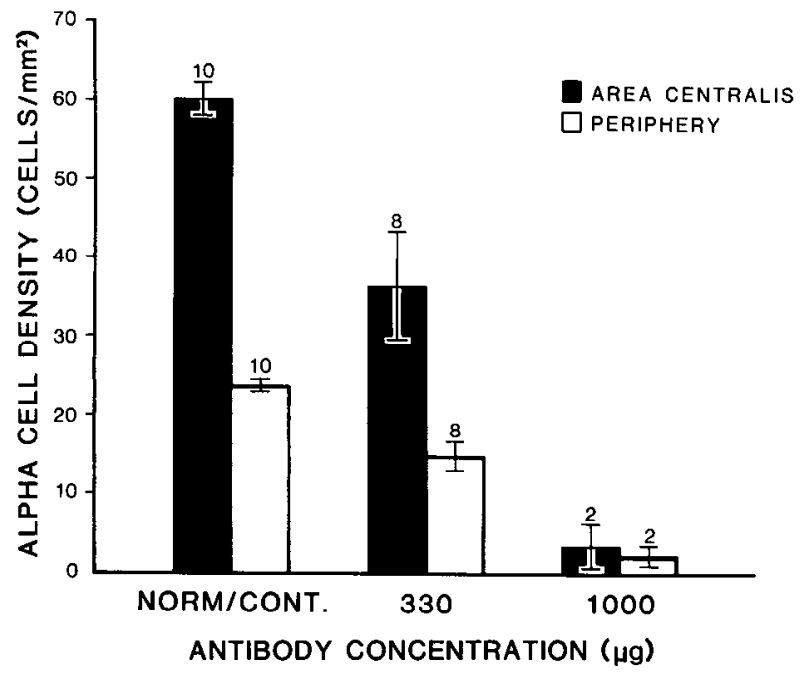

Figure 4. Number of retinal alpha-cells $\left(\right.$ per $\left.\mathrm{mm}^{2}\right)$ in the area centralis and peripheral retina of normal or control-injected eyes (NORM/CONT.) and eyes injected with either a low $(330 \mu \mathrm{g} / 100 \mu \mathrm{l})$ or high $(1000 \mu \mathrm{g} /$ $100 \mu$ l) antibody concentration. For peripheral retina, data from the four sample areas are combined. Bars represent means and brackets represent SEM of the number of alpha-cells in individual animals. The number above each bar gives the total number of eyes in which alphacells were counted. 

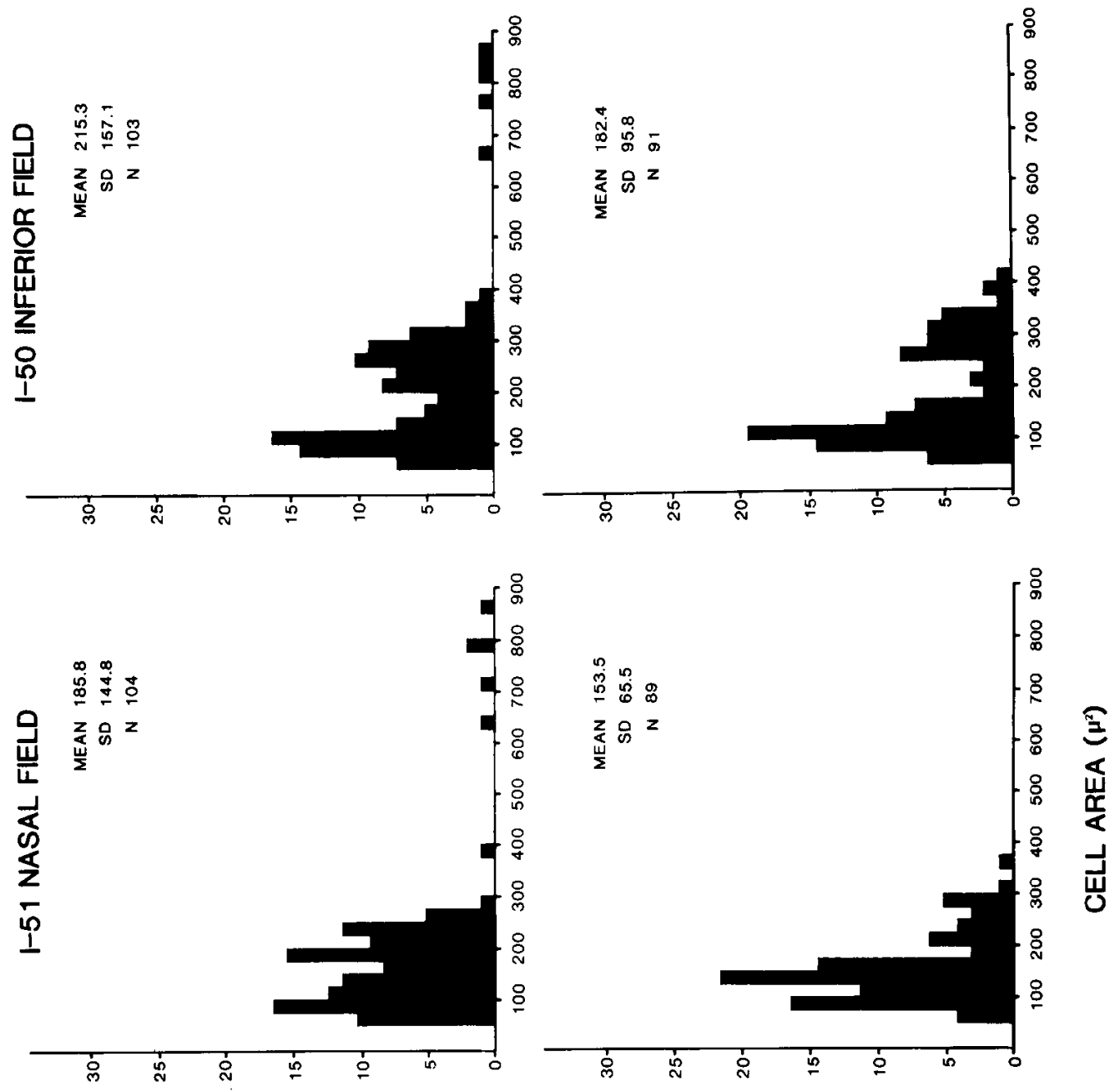

एँ

速产

害哭

昏

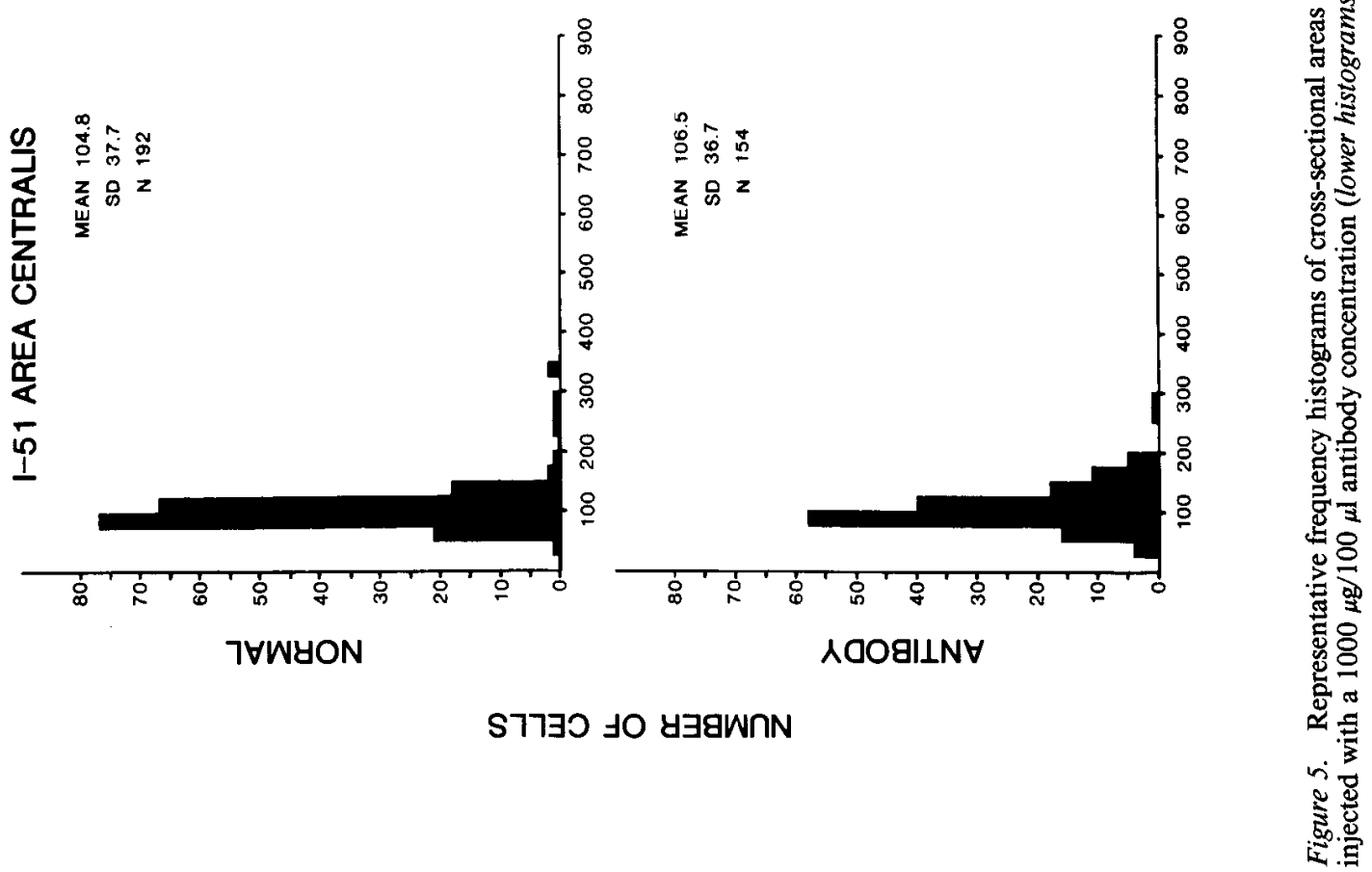


of alpha-cells in both area centralis and peripheral retina, and the loss was much greater following high-concentration than low-concentration injections. The low-concentration injection produced a $41 \%$ average loss (range $4-83 \%$ ) in area centralis and a $35 \%$ average loss (range $5-64 \%$ ) in peripheral retina. In the two cats given a high-concentration injection, there was a 90-99\% loss in area centralis and an 88-97\% loss in peripheral retina. Unlike the patchy loss of alpha-cells seen in eyes given a low-concentration injection (Kornguth et al., 1982), the loss was relatively uniform across the retina of eyes given a highconcentration injection.

\section{Soma sizes and numbers}

lo determine whether large (alpha) ganglion cells were affected selectively by the high concentration of antibodies, measurements were made of ganglion cell sizes in the retinae of the two cats that received a $1000 \mu \mathrm{g}$ injection (see Materials and Methods). In all four areas sampled in the peripheral retina, the cellsize histograms in normal eyes consisted of two modes and a tail (Fig. 5, upper middle and right). The tail corresponds to the large (alpha) cells and the two modes correspond to the medium and small ganglion cells. Considering each peripheral retinal sampling area separately, the mode of medium-size cells was reduced 24 to $57 \%$ (mean $45 \%$ ) in the antibody-treated eye compared to the normal eye. In contrast, there was no consistent change in the number of ganglion cells in the small-cell mode of the distributions. For all peripheral retinal areas, there was an average of 3\% more cells in the small-cell mode of antibodytreated eyes compared to normal eyes.

Unlike peripheral retina, the medium and small ganglion cells of area centralis do not form two distinct modes (cf. Fukuda and Stone, 1974; Hughes, 1981; Rowe and Stowe, 1976b; Wässle et al., 1975). Therefore, we could not distinguish between effects on the medium and small ganglion cells of area centralis. Considering the single cell-size mode as a whole (excluding the tail of the distribution), there was an 18-19\% loss of medium/ small ganglion cells in the antibody-treated eye relative to the normal eye of each cat.

\section{LGN neurophysiology}

We next studied the LGN to determine how the effects in the retina are reflected in a major central target of the retinofugal pathways. Recordings were made from LGN neurons in six cats that received a monocular injection of the highcst antibody concentration (1000 $\mu \mathrm{g} / 100 \mu \mathrm{l}$ volume). Four of the cats had a control gamma-globulin injection in the other eye, and two of the cats had no injection in the other eye. (One of these cats also was used for retinal field-potential recording.) LGN recordings were made 34-503 d after the injections, and there was no relationship between survival time and the results that were obtained. Results from a previous study (Spear et al., 1982) of seven normal adult cats and seven cats with a monocular injection of the lowest antibody concentration $(330 \mu \mathrm{g} / 100 \mu \mathrm{l})$ were included for comparison.

\section{Normal cats}

In normal cats, $38 \%$ (74 of 194) of the LGN cells encountered were Y-cells and $57 \%$ (110 of 194) were X-cells. The remaining cells had mixed $\mathrm{X}$ and $\mathrm{Y}$ properties or responded too poorly to be classified (Fig. 6A).

\section{Antibody-injected cats}

Laminae with inputs from injected eye. In cats with a highconcentration injection, Y-cells accounted for only $5 \%$ (4 of 85 ) of the neurons encountered in laminae with inputs from the antibody-treated eye (referred to as antibody laminae). Compared to normal cats, this represents an $87 \%$ loss of LGN Y-cells following the high-concentration injections. This loss was seen

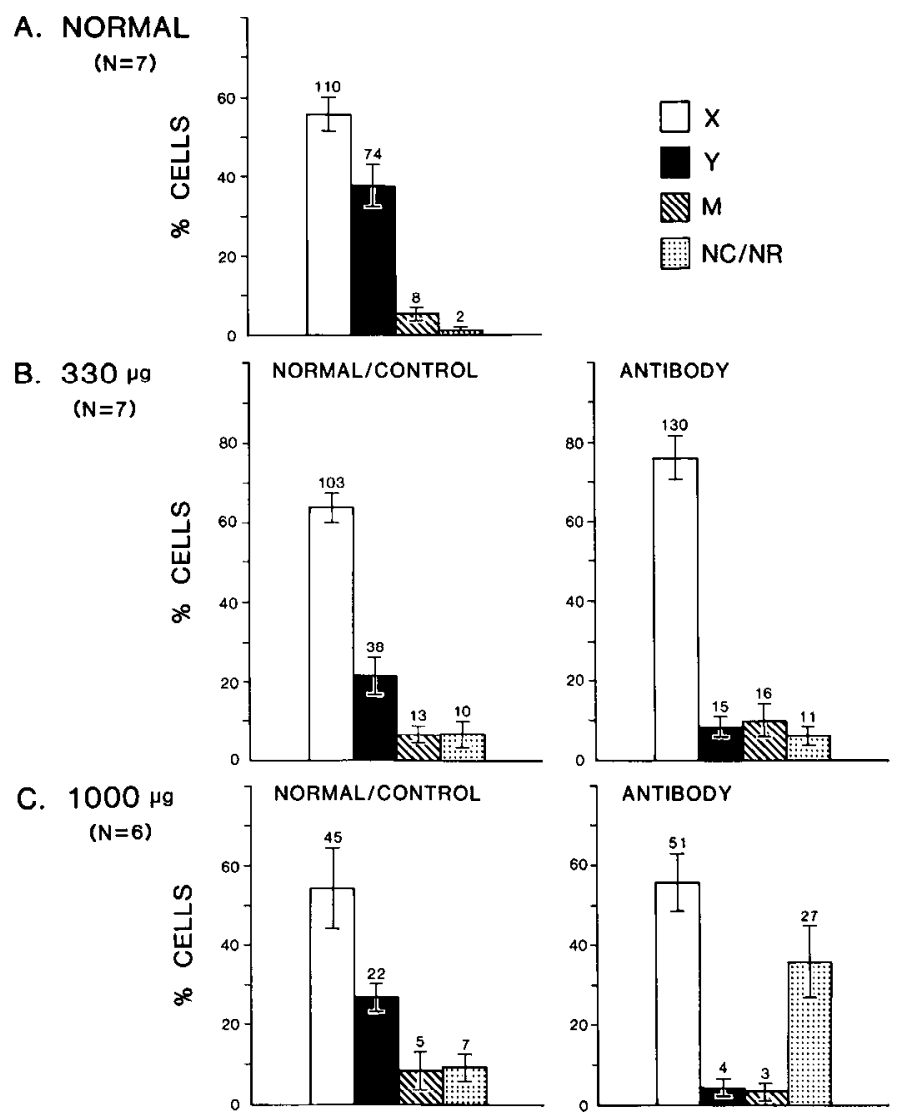

Figure 6. Percentage of X-cells $(\square)$, Y-cells $(\square)$, cells with mixed X and $Y$ properties $(\mathbb{Q})$, and nonclassifiable or nonresponsive $(\square)$ cells encountered in recordings from the LGN of $(A)$ normal cats, $(B)$ cats injected monocularly with a low $(330 \mu \mathrm{g} / 100 \mu \mathrm{l})$ antibody concentration, and $(C)$ cats injected monocularly with a high $(1000 \mu \mathrm{g} / 100 \mu \mathrm{l})$ antibody concentration. NORMAL/CONTROL denotes laminae with inputs from a normal eye or a control gamma-globulin-injected eye. ANTIBODY denotes laminae with inputs from the antibody-injected eye in the same cats. $N$ indicates the number of cats in each group. Bars represent means and brackets represent SEM of the percentage of cells in each class encountered among individual animals. All LGN cells studied had receptive fields between $1.5^{\circ}$ and $32^{\circ}$ from area centralis, and about $70 \%$ in each group had receptive fields between $5^{\circ}$ and $15^{\circ}$ from area centralis. Results from laminae A and Al were similar; therefore, they were combined in each cat. The number above each bar gives the total number of cells in a class, pooled across animals.

consistently among individual animals (compare Fig. 6, $A$ and $C$, right; $U=0, p=0.001$ ). Furthermore, the loss of Y-cells in antibody laminae was evident with each of the four tests used to classify the cells.

The reduced percentage of $Y$-cells in antibody laminae was accompanied by an increase in cells that failed to respond to light ( 24 cells) or that responded so poorly ( 3 cells) that they could not be classified (NC/NR cells). All together, 32\% (27 of $84)$ of the cells could not be classified, which is significantly greater than normal $(U=0, p=0.001)$. In contrast, the percentages of $\mathrm{X}$-cells and mixed cells in antibody laminae were not significantly different from normal (compare Fig. 6, $A$ and $C$, right). The receptive-field properties of these cells also appeared normal.

These results suggest that high-concentration intraocular antibody injections produce a selective loss of LGN Y-cells, and that many of the Y-cells become poorly responsive or unresponsive to light. To assess this suggestion more directly, we determined the sampling density of each cell type per penetration through each lamina of the LGN (see Table 1). In antibody 


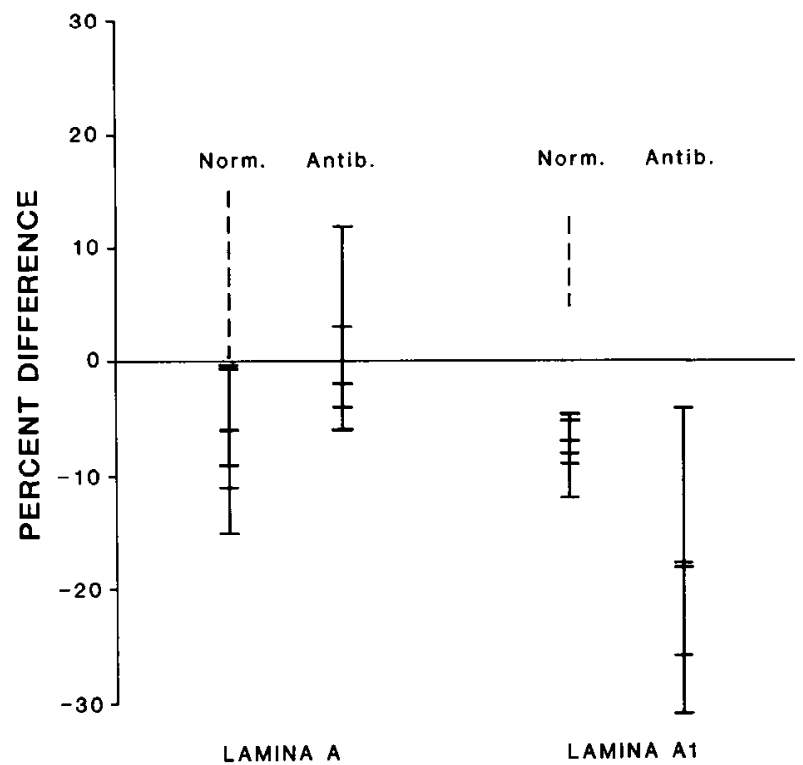

Figure 7. Percent differences between the two hemispheres in mean cross-sectional area of cells in LGN laminae A and A1. Antib. refers to results from five cats that received a high-concentration antibody injection in one eye and no injection or a control gamma-globulin injection in the other eye. The percent difference refers to the size of cells in antibody laminae relative to cells in normal/control laminae in the same cat. Horizontal marks are results for individual animals. Norm. refers to results from six normal cats (data from Spear and Hickey, 1979). In these animals, cells in one hemisphere were always somewhat smaller than those in the same lamina of the other hemisphere. IIorizontal marks show the percent difference in size of the smaller relative to the larger hemisphere for individual animals. The vertical dashed lines show the range of differences obtained when the results are expressed in the opposite way, i.e., in terms of the percent difference in size of the larger relative to the smaller hemisphere.

laminae, the average number of $Y$-cells encountered per penetration was reduced compared to normal $(0.15 \mathrm{vs} 1.45 \mathrm{Y}$-cells penetration, respectively) and the number of NC/NR cells was increased (1.0 vs 0.04$)$. In contrast, there was no appreciable change in the numbers of X-cells or mixed cells per penetration through the antibody laminae. Thus, the antibody-mediated loss of LGN cells was confined to the Y-cells.

Figure $6 B$ (right) shows the results of our previous study of effects of low-conccntration $(330 \mu \mathrm{g} / 100 \mu \mathrm{l})$ antibody injections on LGN neurons in antibody laminae (Spear et al., 1982). In those animals, we found that approximately $9 \%$ (15 of 172) of the cells encountered in antibody laminae were $\mathrm{Y}$-cells, which represents approximately a $77 \%$ loss compared to normal cats. Thus, $1000 \mu \mathrm{g}$ injections of the antibodies produced a slightly greater loss of LGN Y-cells than the $330 \mu \mathrm{g}$ injections. However, the difference between the two conditions was not statistically reliable, largely because no Y-cells were encountered in some animals of both groups.

Note that the cats with a low-concentration injection did not have a substantial increase in NC/NR cells such as that seen in cats with a high-concentration injection (compare Fig. 6, $B$, right, and $C$, right). The reason for this difference is not clear.

Laminae with inputs from normal or control-injected eye. Results in laminae with inputs from the normal eye (normal laminae) or the eye with a control gamma-globulin injection (control laminae) were similar to each other (see also Spear et al., 1982). In cats with a high-concentration antibody injection, the percentage of $Y$-cells in normal/control laminae $(28 \% ; 22$ of 79$)$ was somewhat lower than in normal cats (compare Fig. $6 C$, left, and $A$ ), but the difference was not statistically significant. In our previous study of cats with a low-concentration antibody injection (Spear et al., 1982), we found that the percentage of $Y$-cells in normal/control laminae $(23 \% ; 38$ of 164$)$ was significantly lower than in normal cats (compare Fig. $6 B$, left, and $A$ ). The present results suggest that this is a weak and somewhat inconsistent finding.

Despite a possible effect of the high antibody concentration on the percentage of $\mathrm{Y}$-cells in the normal/control laminae, within-animal comparisons confirmed the substantial loss of $\mathrm{Y}$-cells in antibody laminae. Thus, the percentage of $\mathrm{Y}$-cells encountered in antibody laminae was consistently lower than that in the normal/control laminae of the same cats (compare Fig. $6 C$, right and left). A test for dependent samples indicated that this difference was statistically significant $(t=4.09 ; d f=5$; $p<0.005$ ).

\section{Cell size in the LGN}

To determine if the reduced encounter of Y-cells in antibody laminae of the LGN was accompanied by a reduction in LGN cell size, cross-sectional areas of LGN cells were measured in five cats that received a high-concentration antibody injection in one eye. Three of these cats had a control gamma-globulin injection in the other eye, and two cats had no injection in the

Table 1. Sampling density of LGN cells in each receptive-field class for normal cats and cats with monocular injection of low- or high-antibody concentration

\begin{tabular}{|c|c|c|c|c|c|c|}
\hline \multirow[b]{2}{*}{ Condition } & \multirow{2}{*}{$\begin{array}{l}\text { Number } \\
\text { of pene- } \\
\text { trations }\end{array}$} & \multicolumn{5}{|c|}{ Density (cells/penetration) } \\
\hline & & $\mathrm{X}$ & $\mathrm{Y}$ & M & NC/NR & Total \\
\hline Normal cats & 51 & 2.16 & 1.45 & 0.16 & 0.04 & 3.81 \\
\hline \multicolumn{7}{|l|}{ Experimental cats } \\
\hline \multicolumn{7}{|l|}{$330 \mu \mathrm{g}$ injection } \\
\hline Normal/control laminae & 36 & 2.61 & 1.06 & 0.36 & 0.19 & 4.22 \\
\hline Antibody laminae & 44 & 2.95 & 0.34 & 0.36 & 0.25 & 3.90 \\
\hline \multicolumn{7}{|l|}{$1000 \mu \mathrm{g}$ injection } \\
\hline Normal/control laminae & 21 & 2.14 & 1.05 & 0.24 & 0.33 & 3.76 \\
\hline Antibody laminae & 27 & 1.89 & 0.15 & 0.11 & 1.00 & 3.15 \\
\hline
\end{tabular}

$X, X$-cells; Y, Y-cells; $M$, cells with mixed $X$ and $Y$ properties; NC/NR, nonclassifiable or nonresponsive cells. Number of penetrations reflects the number of penetrations through a single lamina. Thus, a traverse through laminae $\mathrm{A}$ and $\mathrm{Al}$ in the same hemisphere was counted as two penetrations in this analysis. Antibody laminae are laminae with inputs from an antibody-injected eye. Normal/control laminae are laminae with inputs from a normal eye or an eye injected with control gamma-globulins. 
other eye. The animals were killed $21-503 \mathrm{~d}$ after the injections; there was no relationship between survival time and the results obtained. One of these cats also was used for retinal neurophysiology (field-potentials and single-cell recordings) and retinal anatomy, and two also were used for LGN neurophysiology. All of these animals showed a loss of retinal or LGN Y-cells that was typical of the results presented above.

For each cat, the mean cross-sectional area of cells in normal/ control lamina $\mathrm{A}$ and in antibody lamina $\mathrm{A}$ was determined, and the percentage difference in mean cell size between the two hemispheres was calculated. The same was done for lamina Al. For comparison, differences in cell size between the two hemispheres of six normal cats (data from Spear and Hickey, 1979) were analyzed in the same way. The results are shown in Figure 7.

For lamina A, cells in the antibody lamina were an average of $1 \%$ larger than in the normal/control lamina. Clearly, the results for lamina $\mathrm{A}$ were within the normal range of betweenhemisphere cell-size differences (Fig. 7, lamina A). For lamina $\mathrm{A} 1$, however, cells in the antibody lamina were from 4 to $31 \%$ smaller than those in the normal/control lamina, and the mean difference was $19 \%$. These differences were somewhat larger than the differences between the two laminae A 1 of normal cats (Fig. 7, lamina A1). However, the difference between the two groups did not reach statistical significance $(U=6, p=0.063$; one-tailed).

There was no indication of gliosis, neuronal chromatolysis, or other signs of cell death in the LGN of cats given an intraocular antibody injection. This was so in the animal with the shortest survival time, as well as in the animal with the longest survival after the antibody injection.

\section{Discussion}

\section{Effects of antibodies on $Y$-cell retinogeniculate pathway}

There is good evidence that the T1 wave of the retinal fieldpotential mainly reflects the compound action potentials of Y-cell axons (Cleland et al., 1971; Fukada, 1971; Rowe and Stone, 1976a). Therefore, the $98 \%$ reduction in the amplitude of this wave following injection of the highest antibody concentration strongly suggests that many fewer Y-cells were activated than normal. In addition, the progressive decrease in T1 wave amplitude with increases in antibody concentration provides strong evidence that the antibodies produce a dose-dependent loss of retinal Y-cells.

Single-cell recordings in the retina revealed an $85 \%$ reduction in the sampling density of Y-cells following injection of the highest antibody concentration. Thus, with this concentration, the effect on retinal $Y$-cclls is in agrecment with the effect indicated by the retinal field-potentials. However, in a previous study we found that injection of the lowest antibody concentration did not produce a loss of retinal Y-cells that could be detected with single-cell recording methods (Spear et al., 1982), a result that is not in agreement with the substantial reduction in the $\mathrm{T} 1 \mathrm{amplitude}$ following injection of this concentration. This inconsistency may be due to the $\mathrm{Y}$-cell sampling error that is inherent in single-unit recordings from the retina (Stone, 1973; see Discussion in Spear et al., 1982). Thus, a moderate loss of $\mathrm{Y}$-cells may have gone undetected because of the propensity of microelectrodes to sample inflated proportions of retinal $Y$-cells. Whatever the reason for missing a Y-cell loss in single-cell recordings after treatment with the low antibody concentration, it is clear that a high antibody concentration does produce a substantial loss of retinal Y-cells that can be detected with singlecell recording methods.

$Y$-cells in the cat retina correspond to the alpha-cell morphological class of ganglion cells (Boycott and Wässle, 1974; Cleland et al., 1975; Fukuda et al., 1984; Peichl and Wässle,
1981; Saito, 1983a, b; Stanford and Sherman, 1984). Decreases in the density of alpha-cells were related to the concentration of the antibody. With the highest concentration, the loss of alpha-cells averaged $94 \%$ in area centralis and $92 \%$ in peripheral retina. This is in close agreement with the $90-97 \%$ loss of largecaliber axons in optic nerves of eyes injected with the same antibody concentration (Williams et al., 1985). In addition, the alpha-cell losses are consistent with the physiological results.

It is likely that the depletion of retinal alpha-/Y-cells was due to their destruction and removal from the retina. The alternative is that antibodies caused the somata of these cells to shrink so that they were not included in the alpha-cell counts and were more difficult to sample in single-unit recordings. However, results of an electron-microscopic study of the optic nerves from antibody-treated eyes (Williams et al., 1985) argue against the possibility of cell shrinkage. In these nerves, virtually all large axons were either necrotic or only their remnants remained. Since large optic nerve axons probably are those of alpha-cells (Boycott and Wässle, 1974; Fukuda et al., 1984; Saito, 1983b; Stanford and Sherman, 1984; Williams and Chalupa, 1983), their degeneration suggests that their cell somata (i.e., alphacell somata) also had degenerated.

In close agreement with our findings in the retina, there was a severe $(87 \%)$ reduction in the proportion of $Y$-cells encountered in recordings from $\mathrm{LGN}$ laminae that receive inputs from an eye injected with the highest antibody concentration. Injection of the lowest antibody concentration resulted in a $77 \%$ reduction in the proportion of Y-cells in LGN antibody laminae (Spear et al., 1982). This finding is in accord with the effects of the low antibody concentration on the $T 1$ wave, and suggests that there is a weak dose-dependent effect of the antibodies on the Y-cell pathway through the LGN.

The loss of LGN Y-cells cannot be accounted for by removal or shrinkage of their somata after intraocular injection of the highest antibody concentration. There was no histological indication of cell death in the antibody laminae. In addition, although there was a marginal reduction in mean cell size in antibody lamina $\mathrm{Al}$, the cell-size distribution in antibody lamina A was normal. It is noteworthy that the overall decrease in the encounter rate of $\mathrm{Y}$-cells in antibody laminae can be accounted for entirely by an increase in the encounter rate of nonclassifiable and nonresponsive cells. Thus, our results suggest that most of the LGN Y-cells that received input from highconcentration antibody-injected eyes became nonresponsive or grossly abnormal.

\section{Effects of antibodies on $X$-cell retinogeniculate pathway}

There is good evidence that the $\mathrm{T} 2$ wave of the retinal fieldpotential largely reflects the compound action potentials of X-cell axons (Cleland et al., 1971; Fukada, 1971; Rowe and Stone, 1976a). Therefore, the approximately $70 \%$ reduction in this wave following antibody injection is strong evidence that fewer than normal X-cells had been activated. However, unlike the T1 amplitude, the T2 amplitude did not show a greater reduction with increasing antibody concentration. The reason for this lack of a dose-response relationship is unclear. Perhaps at all antibody concentrations used, the reduction in the T2 amplitude solely reflects the elimination of any Y-cells that contribute to the $\mathrm{T} 2$ wave (e.g., those in area centralis that have relativcly small soma and axon size). However, this is unlikely given the extent to which the T2 amplitude was reduced. Therefore, the field-potential results suggest that the antibodies produce a significant loss of retinal X-cells that is unrelated to antibody concentration over the range tested. In addition, the field-potential results (T1:T2 amplitude ratios) suggest that the effects on the retinal $Y$-cells are substantially greater than those on the $\mathrm{X}$-cells.

Single-cell recordings in the retina also revealed a significant $(53 \%)$ loss of X-cells after injection of the highest antibody 
concentration. Thus, with this concentration, the effect on retinal X-cells is in general agreement with the field-potential results. Our previous study found that the lowest concentration of antibodies had no effect on retinal X-cells (Spear et al., 1982), a result that is not in agreement with the substantial reduction in the $\mathrm{T} 2$ amplitude using the same concentration. Thus, some loss of X-cells appears to have gone undetected following injection of the lowest antibody concentration. It is not clear why a loss of $\mathrm{X}$-cells was detected with single-cell recording after high, but not low, concentration injections.

$X$-cells in the cat retina probably correspond to the beta-cell class of medium-size ganglion cells (Boycott and Wässle, 1974; Fukuda et al., 1984; Saito, 1983a, b; Stanford and Sherman, 1984). In the area centralis, it is not possible to distinguish between small- and medium-size ganglion cells because the distribution of cell sizes is not bimodal. However, there was a $45 \%$ average loss of medium-size ganglion cells in the soma-size distributions for peripheral retina following injection of the highest antibody concentration. In addition, there is a $65-70 \%$ loss in the number of medium-size axons in optic nerves of eyes injected with this antibody concentration (Williams et al., 1985). Both of these results are consistent with the physiological results in eyes treated with the highest antibody concentration.

Several findings suggest that the loss of retinal beta-/X-cells was due to their removal from the retina rather than to a shrinkage of their somata. There was no substantial increase in the number of cells with small soma size in the retinal cell-size distributions. In addition, there is no increase in the number of small caliber axons in optic nerves from antibody-trcatcd cyes (Williams et al., 1985). Moreover, many medium-size axons, presumably issuing from medium-size somata (Boycott and Wässle, 1974; Fukuda et al., 1984; Saito, 1983b; Stanford and Sherman, 1984), were observed to be necrotic, indicating that their somata had degencratcd (Williams et al., 1985).

In contrast to the retina, a normal proportion of $\mathrm{X}$-cells was encountered in recordings from LGN laminae receiving inputs from an eye injected with the highest antibody concentration. It is, of course, possible that there was some loss of LGN X-cells that wcnt undetected. If so, it was substantially less than the LGN Y-cell loss and substantially less than the X-cell loss in the retina. Thus, a relatively large effect in the retina resulted in little or no effect in the LGN. This difference may reflect the nature of convergence patterns of inputs from several retinal X-cells to each LGN X-cell (Cleland et al., 1971; and see below). Partial removal of the retinal inputs may not seriously affect the functional responsivity of an LGN X-cell because remaining retinal X-cells are sufficient to drive the LGN cell. Nevertheless, these LGN X-cells may be abnormal with regard to response properties that were not studied. For example, these cells could be deficient in tests of spatial resolution and spatial contrast sensitivity, which probably depend on a normal retinal mosaic of X-cells.

\section{Effects of antibodies on retinal $W$-cells}

We could not use field-potential recordings to assess effects of the antibodies on retinal $W$-cells because the compound action potentials of W-cell axons do not normally yield a distinct and temporally separate wave deflection (see Fig. 1). Rather, the W-cell contribution to the retinal field-potential appears as a long-duration decremental tail of the T2 wave (see Fig. 1 in G. H. Bishop et al., 1969). Nevertheless, our data from singlecell recordings in the retina suggest that the antibodies have no effect on W-cells. Their sampling density was normal following injection of either the low- or the high-antibody concentration.

Most W-cells in the cat retina probably correspond to the gamma-cell class of small-size ganglion cells (Boycott and Wässle, 1974; Fukuda and Stone, 1974; Fukuda et al., 1984; Rowe and Stone, 1976b; Saito, 1983b; Stanford and Sherman, 1984).
Following injection of the highest antibody concentration, there was no loss in the number of ganglion cells in the small-size mode of the soma-size distribution for all peripheral retinal areas examined. Furthermore, there is no necrosis or loss of small-caliber axons, presumably those of gamma-cells (Boycott and Wässle, 1974; Fukuda et al., 1984; Saito, 1983b; Stanford and Sherman, 1984), in the axon-diameter distributions from optic nerves of antibody-treated eyes (Williams et al., 1985). By themselves, these anatomical results do not provide conclusive evidence that W-cells are unaffected by the antibodies because many W-cells appear to have medium-size somata (Fukuda et al., 1984; Leventhal, 1982; Rowe and Dreher, 1982; Stone and Clarke, 1980). However, the lack of effect on small ganglion cell somata and axons is consistent with the normal sampling density of retinal W-cells.

Further evidence that the antibodies have no effect on W-cells is provided by a recent study of the superior colliculus in cats given binocular injections of the highest antibody concentration (Crabtree et al., 1984). Thesc cats had a substantial loss of the $Y$-cell inputs to the superior colliculus, but there was no loss of the W-cell inputs.

\section{Mechanisms of antibody effects in the retina}

The presence of dose-dependent effects of the antibodies provides further evidence (see Kornguth et al., 1981, 1982; Spear et al., 1982; Williams et al., 1985) that the losses of retinal ganglion cells are mediated immunologically and not by nonspecific toxic effects or nonspecific trauma. In addition, the foregoing discussion has presented evidence that the ganglion cells degenerate and do not simply shrink in size. Previous immunofluorescent and peroxidase-antiperoxidase studies indicate that the immunoglobulins bind to the surface of ganglion cell somata (Kornguth et al., 1981). Presumably, the immunoglobulins cause lysis and subsequent degeneration of the cells.

The observation that increased antibody concentrations produce increased losses of both large- and medium-size ganglion cells raises the possibility that the immunoglobulins simply bind to cell somata according to size rather than according to specific antigens that are related to morphological or functional properties. For example, larger cells offer greater surface area than smaller cells to antibodies injected into the vitreous chamber. Given a greater surface area for binding, the antibodies may more effectively lyse the larger cells. Increased concentrations would simply increase the available immunoglobulins for binding.

While we cannot rule out the possibility that soma size plays a role in the mechanisms of the antibody effects, immunocytochemical studies of these antibodies suggest that antigen specificity is an important factor (Kornguth et al., 1981). For example, these studies indicate that the antibodies show a much greater propensity to bind to the large (alpha) ganglion cells than to other cells of all kinds in retinal sections as well as in wholeretina dispersions. The lack of complete specificity probably occurs because these are polyclonal antibodies that are raised against large ganglion cell fractions, which are not completely pure (Kornguth et al., 1981). On the other hand, the specificity that is achieved probably results from the use of large ganglion cell fractions rather than whole-retina fractions as the immunizing antigen.

\section{Implications for retinogeniculate organization}

Comparisons of the effects of the intraocularly injected antibodies on $\mathrm{X}$ - and Y-cells in the retina and LGN have implications for understanding the organization of retinogeniculate connectivity and processing. For the $\mathrm{Y}$ pathway, a relatively small $(\leq 40 \%)$ loss of retinal $\mathrm{Y}$-cells leads to a relatively large $(\sim 80 \%)$ loss of LGN Y-cells (lowest antibody concentration). In contrast, for the $\mathrm{X}$ pathway, a moderate $(\sim 50 \%)$ loss of retinal 
X-cells leads to little or no loss of LGN X-cells (highest antibody concentration).

These comparisons suggest that there is much more convergence of functional connectivity along the $X$ retinogeniculate pathway than along the $Y$ pathway. High $X$ pathway convergence would explain why LGN cells are protected from a significant loss of retinal cells: Converging inputs from the remaining retinal cells continue to drive the LGN cells. Conversely, low Y pathway convergence would explain why a similar loss of retinal cells does produce a loss of LGN cells: There are few converging inputs from the remaining retinal cells to maintain LGN responsiveness.

\section{Conclusions}

Although some questions remain, the results of this and previous work suggest that polyclonal antibodies against large ganglion cells effectively remove alpha-/Y-cells from the cat's retina. With a sufficiently high concentration of antibodies, this removal is approximately $90 \%$ complete throughout the retina and leads to approximately a $90 \%$ loss of the retinogeniculate $\mathrm{Y}$-cell pathway to cortex. The antibodies also remove significant numbers of X-cells from the retina, but even at the highest concentration tested, the loss of X-cells is much less than that of Y-cells. Furthermorc, the loss of retinal X-cells does not appear to lead to a reduction in the lateral geniculate X-cell pathway, although it remains possible that detailed response properties of LGN $\mathrm{X}$-cells are abnormal. Finally, the evidence suggests that $\mathrm{W}$-cells are unaffected by the antibodies.

\section{References}

Berson, D. M., and J. T. Mcllwain (1983) Visual cortical inputs to deep layers of cat's superior colliculus. J. Neurophysiol. 50: 11431155.

Bishop, G. H., M. H. Clare, and W. M. Landau (1969) Further analysis of fiber groups in the optic tract of the cat. Exp. Neurol. 24: 386-399.

Bishop, P.O., and J. G. McLeod (1954) Nature of potentials associated with synaptic transmission in lateral geniculate of cat. J. Neurophysiol. 17: 387-414.

Bishop, P. O., D. Jeremy, and J. W. Lance (1953) The optic nerve. Properties of a central tract. J. Physiol. (Lond.) 121: 415-432.

Bishop, P. O., W. Burke, and R. Davis (1962) The identification of single units in central visual pathways. J. Physiol. (Lond.) 162: 409431.

Boycott, B. B., and H. Wässle (1974) The morphological types of ganglion cells of the domestic cat's retina. J. Physiol. (Lond.) 240: 397-419.

Cleland, B. G., and W. R. Levick (1974a) Brisk and sluggish concentrically organized ganglion cells in the cat's retina. J. Physiol. (Lond.) 240: 421-456.

Cleland, B. G., and W. R. Levick (1974b) Properties of rarely encountered types of ganglion cells in the cat's retina and an overall classification. J. Physiol. (Lond.) 240: 457-492.

Cleland, B., M. W. Dubin, and W. R. Levick (1971) Sustained and transient neurons in the cat's retina and lateral geniculate nucleus. J. Physiol. (Lond.) 217: 473-496.

Cleland, B. G., W. R. Levick, and H. Wässle (1975) Physiolngical identification of a morphological class of cat retinal ganglion cells. J. Physiol. (Lond.) 248: 151-172.

Cleland, B. G., W. R. Levick, R. Morstyn, and H. G. Wagner (1976) Lateral geniculate relay of slowly conducting retinal afferents to cat visual cortex. J. Physiol. (Lond.) 255: 299-320.

Crabtree, J. W., P. D. Spear, M. A. McCall, K. R. Jones, and S. E. Kornguth (1984) Contributions of Y-and W-cell pathways to response properties of superior colliculus neurons: Comparison of antibody- and deprivation-induced alterations. Soc. Neurosci. Abstr. 10: 298 .

Enroth-Cugell, C., and J. G. Robson (1966) The contrast sensitivity of retinal ganglion cells of the cat. J. Physiol. (Lond.) 187: 517-552.

Fernald, R., and R. Chase (1971) An improved method for plotting retinal landmarks and focusing the eyes. Vis. Res. 11: 95-96.

Fukada, Y. (1971) Receptive field organization of cat optic nerve fibers with special reference to conduction velocity. Vis. Res. 11: 209-227.
Fukuda, Y, and J. Stone (1974) Retinal distribution and central projections of $Y_{-}, X_{-}$, and $W$-cells in the cat's retina. J. Neurophysiol. 37: 749-772.

Fukuda, Y., C-F. Hsiao, M. Watanabe, and H. Ito (1984) Morphological correlates of physiologically identified $\mathrm{Y}-, \mathrm{X}-$, and $\mathrm{W}$-cells in cat retina. J. Neurophysiol. 52: 999-1013.

Geisert, E. E., P. D. Spear, S. Zetlan, and A. Langsetmo (1982) Recovery of Y-cells in the lateral geniculate nucleus of monocularly deprived cats. J. Neurosci. 2: 577-588.

Hochstein, S., and R. M. Shapley (1976) Quantitative analysis of retinal ganglion cell classifications. J. Physiol. (Lond.) 262: 237-264.

Hoffmann, K-P., J. Stone, and S. M. Sherman (1972) Relay of receptive-field properties in dorsal lateral geniculate nucleus of the cat. J. Neurophysiol. 35: 518-531.

Hughes, A. (1975) A quantitative analysis of the cat retinal ganglion cell topography. J. Comp. Neurol. 163: 107-128.

Hughes, A. (1981) Population magnitudes and distribution of the major modal classes of cat retinal ganglion cell as estimated from HRP filling and a systematic survey of the soma diameter spectra for classical neurones. J. Comp. Neurol. 197: 303-339.

Kolb, H., R. Nelson, and A. Mariani (1981) Amacrine cells, bipolar cells and ganglion cells of the cat retina: A Golgi study. Vis. Res. 21: 1081-1114.

Kornguth, S., E. Langer, and G. Scott (1981) Antigenic properties of large ganglion cells isolated from ox retina. Exp. Eye Res. 33: 413432 .

Kornguth, S. E., P. D. Spear, and E. Langer (1982) Reduction in numbers of large ganglion cells in cat retina following intravitreous injection of antibodies. Brain Res. 245: 35-45.

Lennie, P. (1980) Parallel visual pathways: A review. Vis. Res. 20: $561-594$

Leventhal, A. G. (1982) Morphology and distribution of retinal ganglion cells projecting to different layers of the dorsal lateral geniculate nucleus in normal and Siamese cats. J. Neurosci. 2: 1024-1042.

Lcventhal, A. G., R. W. Rodicck, and B. Dreher (1985) Central projections of cat retinal ganglion cells. J. Comp. Neurol. 237: 216-226.

Peichl, L., and H. Wässle (1981) Morphological identification of onand off-centre brisk transient $(\mathrm{Y})$ cells in the cat retina. Proc. R. Soc. Lond. [Biol.] 212: 139-156.

Rowe, M. H., and B. Dreher (1982) Retinal W-cell projections to the medial interlaminar nucleus in the cat: Implications for ganglion cell classification. J. Comp. Neurol. 204: 117-133.

Rowe, M. H., and J. Stone (1976a) Conduction velocity groupings among axons of cat retinal ganglion cells, and their relationship to retinal topography. Exp. Brain Res. 25: 339-357.

Rowe, M. H., and J. Stone (1976b) Properties of ganglion cells in the visual streak of the cat's retina. J. Comp. Neurol. 169: 99-126.

Saito, H-A. (1983a) Pharmacological and morphological differences between $\mathrm{X}$ - and $\mathrm{Y}$-type ganglion cells in the cat's retina. Vis. Res. 23; 1299-1308.

Saito, H-A. (1983b) Morphology of physiologically identified X-, Y-, and W-type retinal ganglion cells of the cat. J. Comp. Neurol. 221; 279-288.

Schiller, P. H., and J. G. Malpeli (1977) Properties and tectal projections of monkey retinal ganglion cells. J. Neurophysiol. 40:428-445.

Sherman, S. M., and P. D. Spear (1982) Organization of visual pathways in normal and visually deprived cats. Physiol. Rev. 62: 738855.

Spear, P. D., and T. L. Hickey (1979) Postcritical-period reversal of effects of monocular deprivation on dorsal lateral geniculate cell size in the cat. J. Comp. Neurol. 185: 317-328.

Spear, P. D., K. R. Jones, S. Zetlan, E. E. Geisert, and S. Kornguth (1982) Effects of antibodies to large ganglion cells on the cat's retinogeniculate pathway. J. Neurophysiol. 47: 1174-1195.

Stanford, L. R., and S. M. Sherman (1984) Structure/function relationships of retinal ganglion cells in the cat. Brain Res. 297: 381-386.

Stone, J. (1973) Sampling properties of microelectrodes assessed in the cat's retina. J. Neurophysiol. 36: 1071-1079.

Stone, J. (1978) The number and distribution of ganglion cells in the cat's retina. J. Comp. Neurol. 180: 753-772.

Stone, J. (1983) Parallel Processing in the Visual System: The Classification of Retinal Ganglion Cells and its Impact on the Neurobiology of Vision, Plenum, New York.

Stone, J., and R. Clarke (1980) Correlation between soma size and dendritic morphology in cat retinal ganglion cells: Evidence of further variation in the gamma-cell class. J. Comp. Neurol. 192: 211-217. 
Stone, J., and Y. Fukuda (1974) Properties of cat retinal ganglion cells: A comparison of W-cells with $\mathrm{X}$ - and Y-cells. J. Neurophysiol. 37: 722-748.

Stone, J., and K-P. Hoffmann (1972) Very slow-conducting ganglion cells in the cat's retina: A major, new functional type? Brain Res. 43: 610-616.

Stone, J., B. Dreher, and A. Leventhal (1979) Hierarchical and parallel mechanisms in the organization of visual cortex. Brain Res. Rev. 1: 345-394.

Tong, L., P. D. Spear, R. E. Kalil, and E. C. Callahan (1982) Loss of retinal $\mathrm{X}$-cells in cats with neonatal or adult visual cortex damage. Science 217: 72-75.
Wăssle, H., W. R. Levick, and B. G. Cleland (1975) The distribution of the alpha type of ganglion cell in the cat's retina. J. Comp. Neurol. 157: 419-438.

Williams, R. W., and L. M. Chalupa (1983) An analysis of axon caliber within the optic nerve of the cat: Evidence of size groupings and regional organization. J. Neurosci. 3: 1554-1564.

Williams, R. W., J. W. Crabtree, L. M. Chalupa, P. D. Spear, and S. E. Kornguth (1985) Selectivity of antibody-mediated destruction of axons in the cat's optic nerve. Brain Res. 336: 57-66.

Wilson, P. D., M. H. Rowe, and J. Stone (1976) Properties of relay cells in cat's lateral geniculate nucleus: A comparison of W-cells and X- and Y-cells. J. Neurophysiol. 39: 1193-1 209. 